\title{
THE CRISIS IN IRELAND IN I648: THE NUNCIO AND THE SUPREME COUNCIL: CONCLUSIONS
}

In a number of articles I have discussed the events leading to Archbishop Rinuccini's censure of the supporters of the truce with Inchiquin in May I648, and outlined some of the more important of the many controversies which arose from it. ${ }^{1}$ In this article I hope to round off the question by discussing the defence put forward for their courses of action by Rinuccini and the Supreme Council of the confederation respectively. In addition, it will be useful to consider the analysis of the situation made by Rinuccini's chief apologist, one might say indeed his semi-official apologist, as this introduces points which help us to assess more fully the value of Rinuccini's self-defence.

\section{RINUCCINI'S DEFENCE OF HIS PROCEDURE}

The many controversies arising from the censure do not seem to have carried a great deal of weight for Rinuccini himself. In spite of all the arguments which could be, and were to be, alleged against his actions, he seems to have remained convinced that he had taken the right course, indeed the only possible one.

The evidence for this statement comes from two classes of documents of a different character. The first consists of his correspondence with his Roman superiors between May I648 and his final report on his mission, which he made to Innocent $\mathrm{X}$ on his return to Rome. These documents will be found most conveniently assembled, and in the original Italian, in Aiazzi, Nunziatura in Irlanda. The second is more miscellaneous. It consists of pronouncements addressed to the Irish Confederation between the sentence of excommunication and his departure from the country, which were made with the object of discrediting the truce with

1 Cf. " Rinuccini's censure of 27 May 1648," in I.T.Q., vol. XVIII, pp. 322-37 (October 1951) ; "John Callaghan and the controversies among the Irish in Paris," ibid., vol. XXI, pp. 32-50 (January 1954); " Two contemporary historians of the confederation of Kilkenny: John Lynch and Richard O'Ferrall," in I.H.S., vol. VIII, pp. 217-36 (March 1953).

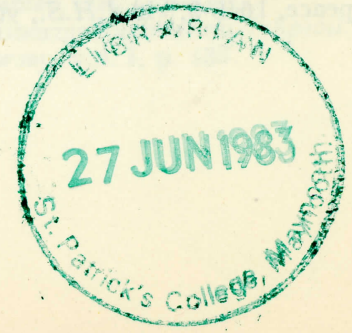


Inchiquin and the Supreme Council who had negotiated it. Almost all these documents have been incorporated into Commentarius Rinuccinianus, with one notable exception, which is the most comprehensive attack on the truce from this point of view. It seems to been printed unown to the compilers of Comment. Rinucc., but has Perhaps the Moran from a copy in the Wadding MSS., Rome. ${ }^{1}$ is that in each Rinuccini thing about both sets of documents action. From this it might the same arguments to justify his was it his primary preoccupt well be argued that in neither case Rather, he was content to to justify himself to his audience. is true that on some to let the facts speak for themselves. It gives to the opposite view debatable points the little weight he points in his defence. perceive the weakness, and, all in equally well argue a failure to interpretation. He seems to in all, this latter seems the correct convictions on one occasion to have been really disturbed in his the bishop of Ferns, on his only. This was when Nicholas French, produced a letter from one of the from Rome in November 1648 , that the censure had not been aprdinals which seemed to indicate however, the nuncio received approved at Rome. In December, superior, Cardinal Panciroli, a letter from his own immediate what some people in Rome might the assured him that, no matter formal decision being taken against hi, there was no question of a letter was in cipher, and when the his action. Unfortunately this he found that it was insufficient nuncio appealed to its authority Ireland; even more unforturicient to change any convictions in him to deal with the unfortunately, the official brief, empowering lost in transit. So the rter as he thought fit, seems to have been strengthened Rinuccini's same time destroyed his hope that he had been right, at the confederate Catholics who hope of convining those of the Irish

Rinuccini's argument was had disagreed with him. ${ }^{2}$ was a matter in which was basically simple. The proposed truce

${ }^{1}$ Moran, Spicil Ossor vol deeply con-

the literature of the period has recently been edited considerable contribution to O.F.M. (Catholic Scritture Antiche, vol. 298, ff. 93-124, by original in Archivio di with Inchiquin written, vol. I, pp. 405-23). It is an account of Rev. Benignus Millett, While it is a valuable addition tonisio Massari, dean of Fermo the truce-negotiations written in an incisive andition to our sources for the factual details occini's secretary. to that of the nuncio that it will way, it presents us with a point of viegotiations, indeed to refer to it that it will not be necessary to an a point of view so similar

${ }^{2}$ For this incident, more than incidentally.

peace, 1648-9," in I.H.S., vol. VI, pp. 89-90 (September 1948).

cerned.

not reacl spiritual a truce, cause, hac that he which gra should dre fact, the \& Domini, in action thes imposed e: cumstance: in order th

As far as vinced that scrupulosit applies to i their suppo communica might have sidered seri Council too for having simply take Council's ap unless and $\mathrm{u}$ to state as matters in w when the int to take decis arguments ac they are mis Indeed, he a misunderst. returns to th viction, that

1 “ Ragioni per 1648, in Nunziat November 1648 , Ossor., vol. III, 2 "Instruzioni," Ossor., vol. III, pp 


\section{LOGICAL QUARTERLY}

Council who had negotiated it. Almost been incorporated into Commentarius able exception, which is the most comice from this point of view. It seems to compilers of Comment. Rinucc., but has a a copy in the Wadding MSS., Rome. ${ }^{1}$ $g$ thing about both sets of documents ses the same arguments to justify his $t$ well be argued that in neither case ation to justify himself to his audience. let the facts speak for themselves. It debatable points the little weight he night argue a wish to gloss over weak it could equally well argue a failure to all in all, this latter seems the correct to have been really disturbed in his only. This was when Nicholas French, return from Rome in November 1648 , f the cardinals which seemed to indicate een approved at Rome. In December, red a letter from his own immediate which assured him that, no matter might think, there was no question of a against his action. Unfortunately this en the nuncio appealed to its authority fficient to change any convictions in inately, the official brief, empowering as he thought fit, seems to have been surance from Cardinal Panciroli, which uviction that he had been right, at the ope of convinaing those of the Irish ad disagreed with him. ${ }^{2}$

basically simple. The proposed truce interests of religion were deeply con-

p. 55-78. Another considerable contribution to atly been edited from the original in Archivio di , vol. 298, ff. 93-124, by Rev. Benignus Millett, 55-23). It is an account of the truce-negotiations Massari, dean of Fermo, Rinuccini's secretary. sources for the factual details of the negotiations, $y$, it presents us with a point of view so similar : be necessary to analyse it separately here, nor dentally.

Bishop Nicholas French and the second Ormond p. 89-90 (September 1948).

\section{THE IRISH CRISIS OF I648: CONCLUSIONS}

cerned. Therefore the Supreme Council of the confederation might not reach agreement with Inchiquin without the consent of the spiritual authority. This consent had not been obtained. Instead, a truce, which was neither useful nor necessary to the confederate cause, had been made with a perfidious heretic, whose record showed that he could not be trusted. This truce contained provisions which gravely prejudiced the Catholic religion. That such a truce should draw down excommunication was in no way surprising. In fact, the general law of the church, specifically the bull In coenam Domini, imposed an ipso facto censure in such circumstances. His action then was little more than a declaration of the law. He had imposed excommunication by formal sentence because, in the circumstances in which he found himself, it was necessary to do so in order that the full effects of the censure should be appreciated. ${ }^{1}$

As far as the appeal from the censure is concerned, he was convinced that its motive was political interest rather than religious scrupulosity, and "frivolous" is the adjective which he usually applies to it. He differs completely from the Supreme Council and their supporters in his estimate of its effects on his sentence of excommunication. The possibility that the making of the appeal might have suspended the sentence he does not seem to have considered seriously at all. He makes so little of what the Supreme Council took for granted that he constructs no elaborate defence for having allowed a merely devolutive effect to the appeal. He simply takes it for granted that even though he had admitted the Council's appeal his sentence of excommunication remained valid unless and until the Pope should decide against him. He is satisfied to state as a well-known and admitted fact that there are some matters in which no suspensive appeal can be allowed, particularly when the interests of religion were imperilled and it was necessary to take decisive action to defend them. In reply to the elaborate arguments adduced by the Council's advocates he simply says that they are misguided and have misunderstood the whole situation. ${ }^{2}$

Indeed, he is so convinced that their attitude must be based on a misunderstanding of the question at issue that he several times returns to the thought, which seems to have been his secret conviction, that the action of the Council has been so indefensible

1 “ Ragioni per le quali il nunzio si è mosso a procedere alle scomuniche," 15 June 1648 , in Nunziatura, pp. 316-7; " Instruzioni al P. D. Giuseppe Arcamoni," 11
November 1648, ibid., pp. 344-6 ; "Declinantis Hiberniae speculum," in Spicil. Ossor., vol. III, pp. 68-70. So also Massari, cf. Catholic Survey, vol. I, p. 429.

2 "Instruzioni," Nunziatura, p. 353 ; "Declinantis Hiberniae speculum," Spicil. Ossor., vol. III, pp. 71-2. So also Massari, cf. Catholic Survey, vol. I, p. 432. 
that it is not too much to say that they are heretics. In arrogating to themselves the spiritual power and in refusing to stand corrected for their transgression, they have ceased to be Catholics. He has always suspected the sincerity of Anglo-Irish Catholicism, and now, he thinks, his suspicions have been confirmed. Their longcontinued practice of accommodating themselves to heresy has borne its natural fruit; they have gone the way of Henry VIII and Elizabeth. ${ }^{1}$

The basic simplicity of his argument is, however, somewhat disturbed when he has to take account of the tangle of events which had led to the censure. In spite of the fact that he had argued that the censure should follow automatically once the truce had been concluded, he several times admits that he would not in fact have had recourse to censure were it not for Preston's manifest determination to attack O'Neill. ${ }^{2}$ While this might be considered as another useful line of defence against the criticism which he had reason to fear would be forthcoming in Rome, it seems incompatible with the argument that the censure was an inevitable consequence of the truce, and, when events sorted themselves out in later controversy, and it was realized that Preston had not in fact been preparing any hostile move against O'Neill, the position of the defenders of the censure was not strengthened.

Another matter on which he had to insure himself with his Roman superiors concerned the repeated instructions he had received not to interfere by censure in any truce or peace-negotiations by the government. ${ }^{3}$ He meets this difficulty by stressing the desperate nature of his situation, in which a formal sentence of excommunication was the only way to protect the vital interests of the church. ${ }^{4}$ This he says was his own conviction, and those whom he consulted had been in complete agreement with him,

${ }^{1}$ Cf. Rinuccini to the nuncio in Paris, Galway, 2 July 1648 : “ negl' interessati è stato ricevuto con molto disprezzo, e come interviene nei regni addomesticati con l'eresia" (Nunziatura, p. 322) ; "Instruzioni ": " persone cattoliche sole di nome" (ibid., p. 350); Rinuccini to Panciroli, St. Vaast, 14 March 1649 : “ tengono quasi i medesimi concetti di Enrico VIII, de della Regina Elisabetta." (ibid., p. 362). Cf. also ibid., pp. 318, 348-9, "Declinantis Hiberniae speculum," Spicil. Ossor., vol. III, pp. 72-8.

${ }_{2}^{2}$ Rinuccini to Panciroli, Galway, 21 August 1648, Nunziatura, p. 331 ; “ Instruzioni," ibid., pp. 346-7.

3 Cf. "Rinuccini's censure of 27 May 1648 ", in I.T.Q., vol XVIII, p. 331.

4 "Ragioni per le quali etc," in Nunziatura, p. 317 ; Rinuccini to the nuncio in Paris, Galway, 2 July 1648, ibid., p. 322.

indee

$\mathrm{Hi}$

Not

comn

those

Subs

stooc

At

retor in $I 6$ more were safet Rinu with

Rinu was of $\mathrm{I}$ nunc diffic

the app supp four thou only the $\mathrm{He}$ anir 


\section{DLOGICAL QUARTERLY}

say that they are heretics. In arrogating power and in refusing to stand corrected y have ceased to be Catholics. He has cerity of Anglo-Irish Catholicism, and ions have been confirmed. Their longommodating themselves to heresy has ey have gone the way of Henry VIII

II

his argument is, however, somewhat ke account of the tangle of events which spite of the fact that he had argued that automatically once the truce had been admits that he would not in fact have re it not for Preston's manifest deter.$^{2}$ While this might be considered as nce against the criticism which he had orthcoming in Rome, it seems incomthat the censure was an inevitable conwhen events sorted themselves out in is realized that Preston had not in fact move against O'Neill, the position of e was not strengthened.

$h$ he had to insure himself with his the repeated instructions he had resure in any truce or peace-negotiations eets this difficulty by stressing the desn, in which a formal sentence of exy way to protect the vital interests ys was his own conviction, and those en in complete agreement with him, 'aris, Galway, 2 July 1648 : “ negl’ interessati è e come interviene nei regni addomesticati con struzioni ": "persone cattoliche sole di nome" li, St. Vaast, 14 March 1649 : " tengono quasi i le della Regina Elisabetta." (ibid., p. 362). Cf. ntis Hiberniae speculum," Spicil. Ossor., vol.

21 August 1648, Nunziatura, p. 331 ; “In-

y $1648 "$, in $I . T . Q .$, vol XVIII, p. 331. Junziatura, p. 317 ; Rinuccini to the nuncio in 322 .

\section{THE IRISH CRISIS OF I648: CONCLUSIONS}

indeed urged him to invoke the censure. ${ }^{1}$

His instructions, however, had been definite, it might be argued. Not altogether, Rinuccini claimed. Recourse was had to excommunication in 1648 in circumstances almost identical with those of 1646 . The excommunication of 1646 had been approved. Subsequent instructions not to proceed to censure must be understood in the light of this approval of the censure of $1646 .{ }^{2}$

At first sight this argument appears unanswerable. It could be retorted, of course, that he had succeeded in 1646 and had failed in I648, and a deeper consideration of this retort shows it to be more than an altogether empirical judgment. The circumstances were almost identical, but not entirely so. The narrow margin of safety in 1646 was considerably narrower two years later, and Rinuccini had to face the argument that his experience, together with his instructions, should have counselled caution.

Finally, there was the problem of his authority to excommunicate. Rinuccini met this difficulty by saying that the excommunication was the act of the properly delegated representatives of the bishops of Ireland, and that in any case his own personal authority as nuncio was sufficient. Neither defence was altogether free from difficulties.

His attempts to show that the bishops' meeting in Kilkenny had been a national synod involve him in some strange statements. Perhaps the most extraordinary is a claim he made in a letter to the Supreme Council. In this he said that the decree of the bishops appointing delegates with power to proceed to censure had the support of eighteen bishops, fourteen present at the meeting and four who subsequently signified their assent to its decisionsthough it had been called as a meeting of the Munster bishops only $!^{3}$ In his reports to Rome, he was content to stress that the consent of the bishops at Kilkenny had been unanimous. ${ }^{4}$ He should, however, have known better than most that the "unanimity" of the bishops was very qualified, and his claim could

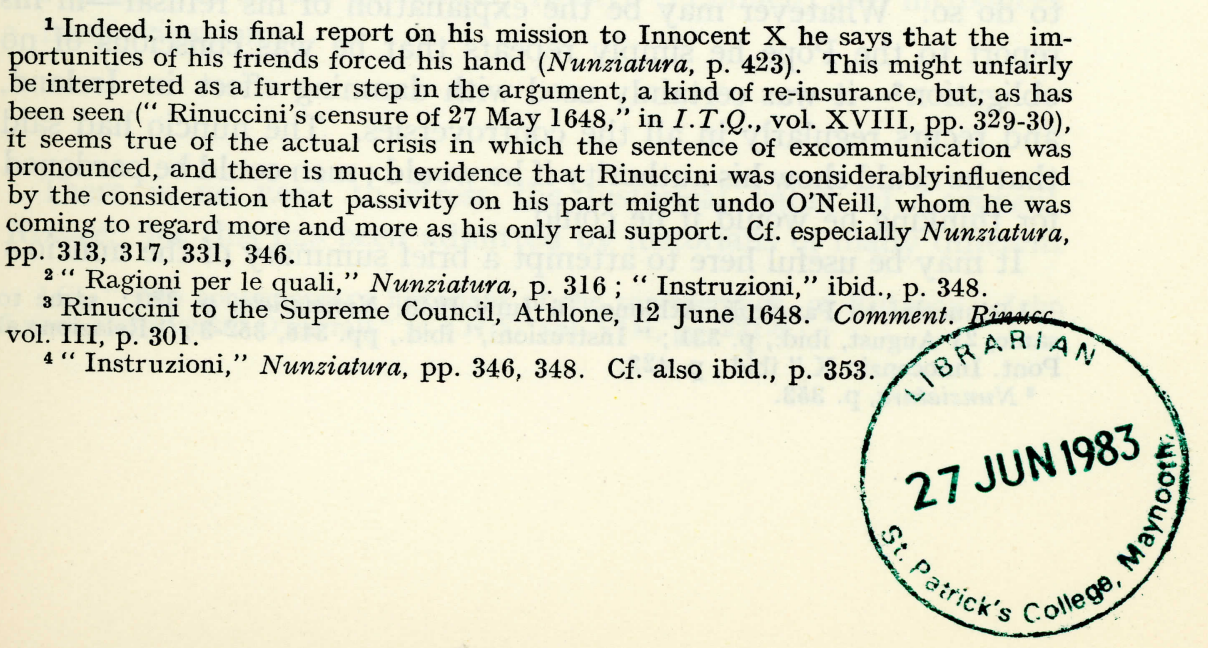


not easily be sustained when some of those who had signed the decree in Kilkenny denounced it later in 1648 and declared that they had never willingly agreed to it.

There still remained the difficulty arising out of the circumstances in which he had chosen the substitute delegates who had actually signed the decree of excommunication. Here he simply says that according to the terms of the Kilkenny decision he had summoned those who had been there named as delegates; that they had refused to attend, and that he had then invoked the authority which had been entrusted to him and had chosen substitutes in their place. In consequence, his action had been perfectly legal, and the excommunication valid. ${ }^{1}$ It will be noticed that he evades the difficulty that those originally delegated, while in fact they did ultimately refuse to obey his summons, had got no opportunity to accept it or reject it before the nuncio had actually issued sentence of excommunication. While it is true that this was no fault of his, it nevertheless remains the point on which it is most difficult to accept his good faith.

His last defence was that his personal authority as nuncio was sufficient to supply any deficiency in the authority of the bishops associated with him. In this he had an undeniably arguable point, but it was weakened by the consideration that the excommunication had in fact been pronounced in virtue of the authority delegated by the bishops' meeting in Kilkenny. It was further weakened, as far as Irish opinion was concerned, by an incident which occurred in Galway on 22 June I648. John de Burgo, archbishop of Tuam, who had with difficulty been restrained from open opposition in Kilkenny, declared his opposition shortly after the excommunication. When the two met in Galway, the archbishop demanded proof of the personal authority which Rinuccini claimed. The nuncio simply repeated that he had such authority, but he refused to produce any document confirming it, claiming that he was under no obligation to do so. Whatever may be the explanation of his refusal-in his report to the Pope he simply repeats that he was conscious of no obligation ${ }^{2}$-it was certainly used with damning effect in Ireland, and recurs regularly in all the controversies. The nuncio had said that he could show his authority if he would ; men could be pardoned for thinking he would if he could.

It may be useful here to attempt a brief summary of the nuncio's

1 Rinuccini to Panciroli, Athlone, 16 June 1648, Nunziatura, p. 320 ; same to same, 21 August, ibid., p. 331 ; “Instruzioni," ibid., pp. 346, 352-3 ; “ Relazione al Pont. Innocenzio X," ibid., p. 423.

${ }^{2}$ Nunziatura, p. 353. legal case. B the practical to force on $h$ coming less e admitted, hov of a real pro

ROBERT

In the con it will be no presented tha most vocal they remain particularly defenders of to compare however, pr contemporar was the Cor

It should of the Coms delimited. unfairly be orandum of underwent plan first to troversies 0 Here, the $d$ will be stri his recourse O'Ferrall, a fresh vie

There is Rinucc., fo ${ }^{1} \mathrm{Cf}$. " Tw Lynch and $\mathrm{R}$ 


\section{LOGICAL QUARTERLY}

nen some of those who had signed the iced it later in 1648 and declared that greed to it.

lifficulty arising out of the circumstances substitute delegates who had actually munication. Here he simply says that he Kilkenny decision he had summoned med as delegates ; that they had refused then invoked the authority which had had chosen substitutes in their place. had been perfectly legal, and the ext will be noticed that he evades the ally delegated, while in fact they did his summons, had got no opportunity efore the nuncio had actually issued on. While it is true that this was no emains the point on which it is most faith.

his personal authority as nuncio was iciency in the authority of the bishops $s$ he had an undeniably arguable point, consideration that the excommunication $d$ in virtue of the authority delegated Kilkenny. It was further weakened, as cerned, by an incident which occurred John de Burgo, archbishop of Tuam, $\mathrm{n}$ restrained from open opposition in tion shortly after the excommunication. y, the archbishop demanded proof of Rinuccini claimed. The nuncio simply thority, but he refused to produce any ning that he was under no obligation the explanation of his refusal-in his repeats that he was conscious of no used with damning effect in Ireland, e controversies. The nuncio had said ty if he would ; men could be pardoned ould.

empt a brief summary of the nuncio's

16 June 1648, Nunziatura, p. 320 ; same to truzioni," ibid., pp. $346,352-3$; “ Relazione al

\section{THE IRISH CRISIS OF I648: CONCLUSIONS}

position. He is clearly convinced that he has an unimpeachable legal case. By all the text-books he has acted rightly. Perhaps the practical difficulties in which he is enmeshed may be beginning to force on his attention the fact that the old formulas are becoming less easy to impose on the new situations. It must be admitted, however, that he gives little evidence that he is conscious of a real problem.

\section{ROBERT O'CONNELL AND THE “COMMENTARIUS RINUCCINIANUS ”}

In the controversial writings which have so far been examined it will be noticed that the Anglo-Irish interest is much better represented than that of the Old-Irish. The Anglo-Irish had been the most vocal party during the years of the Confederation, and such they remained during the disputes which followed. They were particularly successful in getting their writings into print. The defenders of the nuncio or of the Old-Irish party could show nothing to compare with the works of Callaghan or Lynch. They did, however, produce what is unquestionably the most comprehensive contemporary history of the Confederation of Kilkenny. This was the Commentarius Rinuccianus.

It should scarcely be necessary to stress that the examination of the Commentarius Rinuccianus attempted here will be strictly delimited. The main thesis of this great work may not altogether unfairly be said to be represented by Richard O'Ferrall's memorandum of 1658 , but, as has already been suggested, this thesis underwent considerable modification between the time when its plan first took shape in Richard O'Ferrall's mind during the controversies of 1658 and the completion of the manuscript in $1666 .{ }^{1}$ Here, the detailed examination of the Commentarius Rinuccinanus will be strictly confined to its criticism of the nuncio's defence of his recourse to censure in 1648 . This was written, not by Richard O'Ferrall, but by his co-worker, Robert O'Connell, and introduces a fresh viewpoint.

\section{I}

There is no need to stress the historical value of Comment. Rinucc., for this has been admitted by historians of many different

${ }^{1} \mathrm{Cf}$. " Two contemporary historians of the confederation of Kilkenny : John Lynch and Richard O'Ferrall," in I.H.S., vol. VIII, pp. 221-3. 
viewpoints. ${ }^{1}$ In bulk, it dominates all the other sources for the history of the Confederation of Kilkenny, except perhaps the Carte Papers, and it surpasses even these in its comprehensiveness. It was meant to provide a full and satisfactory refutation of the various histories of the confederation which had been written as attacks on the nuncio's policy, notably the work of John Callaghan. The authors had access to all the nuncio's papers, which were in the hands of his family at Florence. These provided incomparably fuller sources than were available to any historian who had previously written of his mission.

The labours of the authors were successful in one respect, for they had sufficient ability to handle their material, and their work must be judged highly as historical scholarship. In another respect they were less successful, for, partly no doubt because of its great bulk, they did not succeed in having their work printed. This has been accomplished only in our own day, in the edition by Fr. Stanislaus Kavanagh, O.F.M.Cap. ${ }^{2}$

The fact that a printed text is now available does not, however, mean that nothing more remains to be done. It means rather that we are now able to begin the process of critical evaluation. This will undoubtedly be a task of considerable magnitude. It will also be a task of no small delicacy, especially in view of the exciting and complicating discovery of the editor, namely that Comment. Rinucc. is the work of two collaborators, both Irish Capuchin friars, Richard O'Ferrall and Robert O'Connell. ${ }^{3}$

From even the most cursory examination of the text it becomes clear that it is important to delimit the exact responsibilities of each, for we are dealing with two markedly different personalities. While it is not necessary for the scope of the present investigation to do this fully, it will be useful to call attention to some of the more obvious facts and make some conjectural deductions.

As has elsewhere been indicated, 4 the task of compiling this defence of the nuncio was first entrusted to Richard O'Ferrall, who began his work at Florence at the end of 1658 or the beginning of I659. It has been seen also that the plan of the work had been evolving in his mind for some time previously, and that he brought to it many clearly-defined preconceptions and prejudices. It is a

${ }^{1}$ Cf. Carte, Ormonde, vol. I, p. v ; Warner, History of the rebellion and civil war in Ireland, p. xv; Russell and Prendergast, Report on the Carte manuscripts, pp. 27, 116 ; J. T. Gilbert, in H.M.C. rep. IX, app. I, pp. 340-57.

2 Six volumes, Ir. MSS. Comm., Dublin, 1932-49.

3 "History and authorship of the Commentarius Rinuccinianus," in Comment. Rinucc., vol. VI, pp. $11 \mathrm{ff}$.

4 "Two contemporary historians of the confederation of Kilkenny," cit., p. 221.

reasonable to him for is quite ce finished w Robert O'C of the wor health. Tl to be almos O'Ferrall's In additior From these time befor the work $t$

This give but the pa if not afte was so fee on it. ${ }^{2} \mathrm{~W}$ we are her

Robert know of $\mathrm{b}$ " clientes

Mór. ${ }^{3}$ Fro Rinucc. it Valentia, c of the gr

1 Kavana

2 The pass original man argues that Comment. $R$ lived in Galv O'Connell fe ingenious, b

3 Except be found ass

4 Robert De praesulib 5 Commer of Ardfert Valentiae $\mathrm{PC}$ principis, cli De praesulit eremus mart\} $(1950)$, p. 75 


\section{LOGICAL QUARTERLY}

lominates all the other sources for the of Kilkenny, except perhaps the Carte en these in its comprehensiveness. It ull and satisfactory refutation of the nfederation which had been written icy, notably the work of John Callaghan. all the nuncio's papers, which were in lorence. These provided incomparably ivailable to any historian who had ssion.

were successful in one respect, for they le their material, and their work must 1 scholarship. In another respect they tly no doubt because of its great bulk, ng their work printed. This has been a day, in the edition by Fr. Stanislaus

xt is now available does not, however, mains to be done. It means rather gin the process of critical evaluation. task of considerable magnitude. It all delicacy, especially in view of the iscovery of the editor, namely that rk of two collaborators, both Irish errall and Robert O'Connell. ${ }^{3}$

$y$ examination of the text it becomes delimit the exact responsibilities of two markedly different personalities. he scope of the present investigation ful to call attention to some of the some conjectural deductions. icated, ${ }^{4}$ the task of compiling this entrusted to Richard O'Ferrall, who the end of 1658 or the beginning of hat the plan of the work had been ime previously, and that he brought conceptions and prejudices. It is a

Warner, History of the rebellion and civil war gast, Report on the Carte manuscripts, pp. 27,
app. I, pp. 340-57.

lin, 1932-49.

Commentarius Rinuccinianus," in Comment. the confederation of Kilkenny," cit., p. 221.

\section{THE IRISH CRISIS OF I648: CONCLUSIONS}

reasonable conjecture that the abundant documentation available to him forced certain modifications of these preconceptions. It is quite certain that what influence they still might have on the finished work was considerably lessened by the appearance of Robert O'Connell as his assistant, particularly as more and more of the work devolved on O'Connell because of O'Ferrall's failing health. The second half of Comment. Rinucc. may be considered to be almost altogether O'Connell's, and to have been written between O'Ferrall's death in I663 and the completion of the work in I666. In addition, most of the first part is in O'Connell's handwriting. ${ }^{1}$ From these considerations it would appear that for a considerable time before O'Ferrall died he was compelled to entrust most of the work to Robert O'Connell.

This gives no final division of responsibility for the earlier portion, but the passage to be examined here was almost certainly written, if not after O'Ferrall's death, at least at a time when his health was so feeble that he could have exercised little or no influence on it. ${ }^{2}$ We may with a fair measure of assurance conclude that we are here dealing with the work of Robert O'Connell.

\section{II}

Robert O'Connell was reticent about himself, but what little we know of his life is instructive. He tells us that his family were "clientes ab aevo haereditarii" of the royal house of MacCarthy Mór. ${ }^{3}$ From his references to the family of O'Connell in Comment. Rinucc. it seems certain that Robert ${ }^{4}$ was born in Ballycarbery, Valentia, co. Kerry, and that his family were the hereditary wardens of the great castle of Ballycarbery for MacCarthy Mór. ${ }^{5}$ His

1 Kavanagh, op. cit., in Comment. Rinucc., vol. VI, p. 5.

${ }^{2}$ The passage is in Comment. Rinucc., vol. III, pp. 262-76 (ff. 1381-1392 of the original manuscript). O'Ferrall's hand last occurs on f. 1319v. Father Kavanagh argues that O'Ferrall died between the writing of f. 1550 and f. 1552 (op. cit., in Comment. Rinucc., vol. VI, p. 15), on the grounds tht he is referred to as "one who lived in Galway at the time " on f. 1550 and by name of $f .1552$. The argument that O'Connell felt free to refer to him by name only after his death may sound a little ingenious, but the high punctiliousness is quite in keeping.

${ }^{3}$ Except where more specific reference is given, the following personal details will be found assembled in Kavanagh, op. cit., Comment. Rinucc., vol. VI, pp. 13, 21.

${ }^{4}$ Robert was his name in religion. His baptismal name was Daniel. Lynch, De praesulibus Hiberniae, vol. II, p. 202.

5 Comment. Rinucc., vol. V, pp. 151 ff., 192. On p. 151 Richard O'Connell, bishop of Ardfert and Aghadoe, is described as having been born " ad Ballicarbriam, Valentiae Portui in Desmonia proximum, parentibus . . . MacCartii Magni, Desmoniae principis, clientibus haereditariis." The bishop was Robert O'Connell's uncle (Lynch, De praesulibus Hiberniae, vol. II, p. 202). Cf. also F. X. Martin (ed.) Sanguinea evemus martyrum Hiberniae Ord. Evemit. S.P. Augustini, in Archiv. Hib., vol. XV, (1950), p. 75 . 
eulogistic references to Donal MacCarthy Mór, who died in exile in I66I at the Irish Capuchin convent of Charleville, also manifest his allegiance. ${ }^{1}$

It may be noted in passing that the MacCarthys of Muskerry, the patrons of John Callaghan, grew during the seventeenth century on the decline of the MacCarthy Mór, and Donough MacCarthy, the Viscount Muskerry of the confederate wars, received from Charles II in 1658 the premier MacCarthy title in English law, that of earl of Clancarty. When he regained his estates after the Restoration he claimed also the title of MacCarthy Mór. O'Connell, then, no less than O'Ferrall, was identified with an interest which was disappearing in the general upheaval, and in addition he had special reasons for disliking John Callaghan.

There were, however, other factors which tempered his approach. He left Ireland as a young student before the outbreak of the Confederate wars. In I640 he was in Bordeaux, and in I645 he was received into the Irish Capuchin convent of Charleville. He was ordained priest in I65I. He lived either at Charleville or at the other Irish Capuchin convent of Sedan until he was sent to Florence to assist Richard O'Ferrall.

His life was less stormy than O'Ferrall's, and this is reflected in his writing. There were undoubtedly differences of temperament, but he was also removed one step further than O'Ferrall from the catastrophe which had come upon their people. In addition, his somewhat less aristocratic family background may have left him with a less fierce attachment to the old order, though both he and John Callaghan show that the position of being a MacCarthy retainer was a sufficient source for such attachment.

He belongs, then, to a younger generation, who can begin to take a slightly more detached view. He is still, however, preoccupied with the same problems. Though he refers to post-Restoration controversies, notably Peter Walsh and the Remonstrance, towards the end of his work, he does so only incidentally, ${ }^{2}$ and it can have meant little to him when he wrote his account of the events of I648.

These conclusions, it must be emphasized, must remain somewhat tentative until a much fuller examination of the problems of Comment. Rinucc. has been made. What is certain is that Robert O'Connell appears as a careful and conscientious historian, whose outlook has certain limitations no doubt, but who anxiously checks the truth of his story with the facts as he knows them. This makes

1 Comment. Rinucc., vol. V, pp. $414 \mathrm{ff}$.

Ibid., vol V, pp. 378-90.

his consic able.

If we he was $c$ is in no Inchiquir should b doubt. was not difficulty tence of delegatec not be $\mathrm{s}$ had beer 2 May I Council Kilkenny and som Kilkenn.

Even sidered to excor consistin had bee the comr lished $\mathrm{p}$ interests for reaso tately fr of this, "absent of the $\mathrm{c}$ Kilkenn inated $\mathrm{b}$ the bish obliged

1 As ha

2 Comm

3 Ibid., 


\section{OGICAL QUARTERLY}

MacCarthy Mór, who died in exile a convent of Charleville, also manifest

that the MacCarthys of Muskerry, the grew during the seventeenth century rthy Mór, and Donough MacCarthy, he confederate wars, received from r MacCarthy title in English law, that regained his estates after the Restoraof MacCarthy Mór. O'Connell, then, dentified with an interest which was heaval, and in addition he had special llaghan.

factors which tempered his approach. student before the outbreak of the e was in Bordeaux, and in 1645 he apuchin convent of Charleville. He He lived either at Charleville or at vent of Sedan until he was sent to errall.

n O'Ferrall's, and this is reflected in ubtedly differences of temperament, step further than O'Ferrall from the pon their people. In addition, his ily background may have left him to the old order, though both he the position of being a MacCarthy for such attachment.

ger generation, who can begin to w. He is still, however, preoccupied ough he refers to post-Restoration lsh and the Remonstrance, towards only incidentally, ${ }^{2}$ and it can have te his account of the events of 1648 . e emphasized, must remain someler examination of the problems of e. What is certain is that Robert and conscientious historian, whose o doubt, but who anxiously checks cts as he knows them. This makes

\section{THE IRISH CRISIS OF I648: CONCLUSIONS}

his considered judgment on Rinuccini's censure particularly valuable.

\section{III}

If we consider Robert O'Connell's background, and the fact that he was committed to the task of writing Rinuccini's apologia, it is in no way surprising that he should consider that the truce with Inchiquin was fit subject for an ecclesiastical censure, and that he should be ready to give the nuncio the benefit of every possible doubt. It is clear nevertheless that his stubbornly honest mind was not altogether satisfied with Rinuccini's procedure. The first difficulty appears immediately - the nuncio in pronouncing sentence of excommunication had claimed to do so in virtue of authority delegated from the bishops of Ireland. This claim, however, could not be strictly true, as no national synod of the Irish hierarchy had been convoked. ${ }^{1}$ The bishops who signed the declaration of 2 May I648 did not constitute a national synod. The Supreme Council of the confederation had invited the bishops of Munster to Kilkenny for consultations with regard to the truce with Inchiquin, and some bishops from the other provinces happened to be in Kilkenny also. ${ }^{2}$ There was, then, no question of a national synod.

Even if in some way this assembly at Kilkenny could be considered to be a national synod, it had delegated power to proceed to excommunication, not to the nuncio alone, but to a committee consisting of the nuncio and four named bishops. True, the nuncio had been given power to choose substitutes for any member of the committee who was absent. Yet the committee had been established primarily to remain at Kilkenny and watch over religious interests in the truce-negotiations with Inchiquin. The nuncio had, for reasons which he no doubt considered sufficient, departed precipitately from Kilkenny without informing his committee. Because of this, a case could be made that if anyone could be said to be "absent" it was the nuncio himself. In addition, the other members of the committee might well raise objections to a meeting outside Kilkenny, especially in a place which could be represented as dominated by the army of O'Neill. One member of the committee, the bishop of Limerick, was, as a member of the Supreme Council, obliged to reside in Kilkenny. ${ }^{3}$

\footnotetext{
1 As had been at Waterford in a similar crisis in 1646

2 Comment. Rinucc., vol. III, p. 262.

3 Ibid., vol. III, p. 265.
} 
Even granted that the nuncio had the right to convoke the four bishops outside Kilkenny, and granted that they had been summoned and had refused to come, and granted that in these circumstances the nuncio had power to choose substitutes for them, his actual choice of the bishops of Cork, Ross, and Down and Connor was most imprudent. Here Robert O'Connell advances the same reasons for the nuncio's imprudence as had John Lynch, who wrote defending the opposing interest-namely that the bishops of Cloyne and Ross should not have been chosen, for the terms of the proposed truce left their dioceses under the control of Inchiquin, and the bishop of Down and Connor should have been excluded, because he was the nephew of Owen Roe O'Neill.

O'Connell, however, has graver objections than imprudence to bring against the nuncio's choice of substitutes. He is forced to admit as being beyond any possible doubt that the nuncio did not await the replies of the archbishop of Dublin and the bishops of Limerick and Killala; that if he had awaited these replies they must have restrained him; that he did not go to Ferbane, the meeting-place he had appointed when summoning the committee ; but that instead he pronounced censure from Maryborough on 27 May I648, three days before the date he had fixed for the meeting of the episcopal committee at Ferbane. ${ }^{1}$

He adds perplexedly that the nuncio, on his own admission, claimed that he had not chosen substitutes for these three bishops until they had refused to answer his summons. In commenting on this claim, O'Connell the apologist fights a losing battle with $\mathrm{O}$ 'Connell the conscientious historian. His efforts as apologist clearly do not convince even himself. Perhaps, he argues, the nuncio's claim was due to a lapse of memory; perhaps he received earlier letters from the three bishops which are not now to be found among his papers. The desperate nature of these suggestions becomes clear when he mentions in passing a third possibilitythat the nuncio's anticipation of his plans was in reality due to his fear of attack by Preston. ${ }^{2} \mathrm{He}$ does not elaborate, but he must have been conscious that he had earlier concluded that Preston had shown no hostile intent before the publication of the censure. ${ }^{3}$

Continuing his criticism, he returns to the point that the nuncio's authority to excommunicate had not emanated from a national synod, and so, even if all the defects in the hurried events of 27

1 Ibid., vol. III, pp. 262-4, 266-7.

2 Ibid., vol. III, p. 267.

3 Ibid., vol. III, pp. 205 ff.

May 1648 could sidered binding at the bishops' sidered to exter at this meeting. Ross and Dow dioceses while $\mathrm{t}$ ]

To meet these that neither arg says, that the ar of 2 May coulc and that he $c$ actually associ: From what foll valid only if $t$ Irish bishops, : which he had is than rumour. ment among meeting in Kil be binding on nor have we.

This dissatis construct a pr in virtue of his was actually 1 bishops' meeti did not adequ records as his authority of $\mathrm{t}$ ] authority in $C$ to the censure that his perse dential reasor

Again, how claim by the $t$ arose from the evidence for $\mathrm{tl}$

1 These are hi III, pp. 267-9.

2 "A nonnulli:

3 Ibid., vol. II

${ }^{4}$ Ibid., vol. II 


\section{OGICAL QUARTERLY}

cio had the right to convoke the four granted that they had been summoned d granted that in these circumstances oose substitutes for them, his actual $\mathrm{k}$, Ross, and Down and Connor was t O'Connell advances the same reasons as had John Lynch, who wrote st-namely that the bishops of Cloyne $n$ chosen, for the terms of the proposed er the control of Inchiquin, and the should have been excluded, because Roe O'Neill.

raver objections than imprudence to loice of substitutes. He is forced to ossible doubt that the nuncio did not oishop of Dublin and the bishops of $f$ he had awaited these replies they that he did not go to Ferbane, the ed when summoning the committee ; nced censure from Maryborough on the date he had fixed for the meeting Ferbane. $^{1}$

the nuncio, on his own admission, en substitutes for these three bishops swer his summons. In commenting apologist fights a losing battle with historian. His efforts as apologist himself. Perhaps, he argues, the pse of memory; perhaps he received shops which are not now to be found perate nature of these suggestions ons in passing a third possibilityof his plans was in reality due to his le does not elaborate, but he must had earlier concluded that Preston ore the publication of the censure. ${ }^{3}$ eturns to the point that the nuncio's ad not emanated from a national defects in the hurried events of 27
May I648 could be explained, the censure still could not be considered binding on the whole country in virtue of the power delegated at the bishops' meeting of 2 May. It is doubtful if it could be considered to extend to the dioceses of the bishops who were present at this meeting. It is doubtful even if the bishops of Clogher, Cork, Ross and Down could legally impose censures effective in their dioceses while they themselves were outside them. ${ }^{1}$

To meet these difficulties he adduces two arguments. It is obvious that neither argument quite convinces him. It might be argued, he says, that the authority of the nuncio as chief delegate of the meeting of 2 May could be considered to extend to the whole of Ireland, and that he could communicate this authority to the bishops actually associated with him in the decree of excommunication. From what follows, it is obvious that he sees that this argument is valid only if the meeting of 2 May was a national synod of the Irish bishops, and the only proof he can offer of this contentionwhich he had in fact already rejected-is based on nothing stronger than rumour. It was rumoured, he says, ${ }^{2}$ that there was an agreement among the bishops that decisions taken at any episcopal meeting in Kilkenny, especially if the nuncio were present, should be binding on all. He has no evidence to supplement this rumour, nor have we. He was probably ill-satisfied himself.

This dissatisfaction appears in that he proceeds immediately to construct a proof that the nuncio had authority to excommunicate in virtue of his office as nuncio. While he admits that the sentence was actually pronounced in virtue of authority derived from the bishops' meeting of 2 May, and that the nuncio at the very least did not adequately distinguish the two sources of his authority, he records as his own conviction that the nuncio appealed to the authority of the meeting of 2 May rather than to his own personal authority in order that there should be no ground for opposition to the censure based on antipathy to his person. While he knew that his personal authority was sufficient, he preferred, for prudential reasons, to stress the authority of the Irish bishops. ${ }^{3}$

Again, however, Robert O'Connell has carefully qualified this claim by the time he has finished proving it. The principal difficulty arose from the fact that the nuncio had been challenged to produce evidence for this personal authority, and had refused. ${ }^{4}$ The nuncio's

\footnotetext{
1 These are his conclusions from a long legal argument, Comment. Rinucc., vol. III, pp. 267-9.

2 "A nonnullis audivi." Comment. Rinucc., vol. III, p. 269.

${ }^{3}$ Ibid., vol. III, pp. 269-70.

${ }^{4}$ Ibid., vol. III, p. 270 ; cf. ibid., pp. $360 \mathrm{ff}$.
} 
own defence had been that he was under no obligation to produce any such evidence of his authority, and that he did not consider it necessary in view of the fact that a similar exercise of authority in I646 had not been challenged. O'Connell admits that this defence is not altogether satisfactory, as in 1646 he had the support of a clear mandate from the national synod at Waterford, and that everyone was aware of this fact. ${ }^{1}$ In addition, it would appear from the nuncio's credentials that the privilege of not disclosing the source of his authority applied only to the grant of favours, not to the imposition of penalties. His instructions had also imposed the general obligation of showing his credentials to the four archbishops. It is strange that he did not show this particular one on this particular occasion to the archbishop of Tuam. ${ }^{2}$

Still, the fact that he did not declare the source of his authority does not, of itself, prove that he had not authority. Had he such authority? The argument becomes involved in details of canon law, and one might reasonably suspect that the argument as constructed by O'Connell never occurred to Rinuccini. Briefly, O'Connell's conclusion is that Rinuccini was a nuncio ordinary, that is to say that certain powers were attached to his office by law, in contrast with a nuncio extraordinary, who was sent to deal with a specific problem, and who had no powers other than those expressly granted to him in connexion with this problem. Among the powers attached by law to the office of nuncio ordinary was the power to excommunicate whole countries and their governments. The Supreme Council knew that Rinuccini was a nuncio ordinary, for as such they had received him in I645. Therefore he had no need to appeal to any specific authority. ${ }^{3}$

O'Connell now raises the obvious objection to this argument. The exordium of the nuncio's credentials had described him as nuncio extraordinary, and then had proceeded to enumerate specified powers granted to him to deal with specified problems. These made no mention of the censuring of governments. His reply is that the nuncio is here described as nuncio extraordinary because he had, in addition to the powers of a nuncio ordinary, very special powers to enable him to deal with the special problems existing in Ireland, and that the existence of these extraordinary powers did not mean that he had not the powers of a nuncio ordinary as well. ${ }^{4}$

There remained the final objection, that even if he had power to

1 Ibid., vol. III, pp. 270, 272.

${ }^{3}$ Ibid., vol. III, pp. $272 \mathrm{f}$.
2 Ibid., vol. III, pp. $270 \mathrm{f}$.

4 Ibid., vol. III, pp. 273-5. invoke

least tv is brief. with re suspenc another

In $\mathrm{sp}$ conclud nuncio munica challeng this an While the mo had a 1 aggrieve

With

limited repay $n$ to hand his dut truth. of the 1 tions of ialist of whose his ingr

After must $\mathrm{r}$ of the peachal titled $Q$ of the by the $r$ illustrio

${ }^{1}$ Ibid

2 Ibid. 
answers given and signed by the said most reverend prelate, and divines. ${ }^{1}$ Having considered the nuncio's position, we must now examine the defence made by his opponents.

The council's preoccupations were very like those of Rinuccini, though there are certain differences of emphasis. There was the same conviction that the case of the opponent was indefensible, but a greater emphasis on the necessity of justifying their own; and whereas Rinuccini, in so far as he applied himself to self-justification, thought first of his superiors in Rome, the council thought first of the support they must win in Ireland. They had not forgotten the lesson of 1646 , and meant to carry conviction this time.

Their first move was to remind all ecclesiastics of their duty to the throne and to the oath of association of the confederation, and to warn them to have nothing to do with the excommunication of "the nuncio and the four bishops." 2 Then, as men seeking ecclesiastical guidance, they submitted seven questions to the bishop of Ossory for his opinion. These questions-the "queries" cerned the whole matter of the truce, the excommunication, and the appeal. Under the auspices of the bishop, a number of ecclesiastics were summoned to Kilkenny to discuss them. Although those who had been invited were not distinguished as supporters of the nuncio, ${ }^{3}$ there seems to have been a few recalcitrants, ${ }^{4}$ and no one seemed anxious to commit himself to a formal opinion condemning the nuncio's action. The discussions dragged on in this way for about six weeks.

A decision became urgent in the closing days of July, when O'Neill's army was very close to Kilkenny. Even in this stronghold of the Supreme Council opinion was very divided, many of the

1 Kilkenny, 1648. Copies will be found in N.L.I. and R.I.A. Haliday Tracts, vol. 58 , no. 59. A note in the N.L.I. catalogue says that " this exceedingly rare pamphlet was reprinted in 1673 and inserted as an appendix to Peter Walsh's Loyal formulary, or Irish remonstrance." I quote from this reprint of 1673 , as being the most accessible.

Some idea of the number of treatises which appeared at Kilkenny during the summer of 1648 may be gathered from the titles listed in Comment. Rinucc., vol. III, pp. 224-5. Se also Bradshaw cat. and Fortescue, Catalogue of the pamphlets relating to the civil war, the commonwealth, and the restoration, collected by George Thomason, 1640-61. What reading I have done in these confirms what might be reasonably suspected, namely that they contain little more than variations on a limited number of basic arguments. I have chosen the Queries for a fairly detailed analysis because this pamphlet was sponsored by the Supreme Council as an official defence.

2 Proclamation of the Supreme Council, 3 June 1648. Carte Papers, vol. XXII, no. 79, printed in Gilbert, Ir. confed., vol. VI, p. 253. Supreme Council to the bishops, 31 May 1648, Comment. Rinucc., vol. III, p. 252.

3 See the list of approbations, Queries, pp. i-iii.

4 Notably John Egan (or MacEgan), S.J. See Irish remonstrance, preface to the reader, p. xlv ; Egan's letter of 9 Feb. 1649, in Moran, Spicil. Ossor., vol. I, p. 321 ; Comment. Rinucc., vol. IV, pp. 59, $71 \mathrm{f}$. 


\section{EOLOGICAL QUARTERLY}

$y$ the said most reverend prelate, and divines. 1 incio's position, we must now examine the jonents.

ations were very like those of Rinuccini, differences of emphasis. There was the case of the opponent was indefensible, on the necessity of justifying their own; so far as he applied himself to self-justiis superiors in Rome, the council thought must win in Ireland. They had not forand meant to carry conviction this time. remind all ecclesiastics of their duty to of association of the confederation, and hing to do with the excommunication of ur bishops." 2 Then, as men seeking y submitted seven questions to the bishop These questions-the "queries" "-conof the truce, the excommunication, and spices of the bishop, a number of ecclesiKilkenny to discuss them. Although ed were not distinguished as supporters ns to have been a few recalcitrants, 4 $s$ to commit himself to a formal opinion ction. The discussions dragged on in this

nt in the closing days of July, when se to Kilkenny. Even in this stronghold inion was very divided, many of the

e found in N.L.I. and R.I.A. Haliday Tracts, vol. alogue says that " this exceedingly rare pamphlet as an appendix to Peter Walsh's Loyal formulary, n this reprint of 1673 , as being the most accessible. eatises which appeared at Kilkenny during the om the titles listed in Comment. Rinucc., vol. III, nd Fortescue, Catalogue of the pamphlets relating ne in restoration, collected by George Thomason a little more than what might be reasonably little more than variations on a limited number the Queries for a fairly detailed analysis because Supreme Council as an official defence.

Council, 3 June 1648. Carte Papers, vol. XXII, vol. VI, p. 253. Supreme Council to the bishops,
ol. III, p. 252.

eries, pp. i-iii.

(an), S.J. See Irish remonstrance, preface to the b. 1649, in Moran, Spicil. Ossor., vol. I, p. 321 ;
1 f.

\section{THE IRISH CRISIS OF I648: CONCLUSIONS}

churches being closed in obedience to the nuncio's censure. Waverers were strongly influenced by the proximity of O'Neill's army. The council knew that their position was a dangerous one, and they began to remind the assembled ecclesiastics, whom they had convoked to provide them with theological justification, that the sooner a decision was forthcoming the better. ${ }^{1}$ Even now, however, the divines were slow to reach a decision, and it was apparently only after ten days' further discussion that one of them declared himself willing to bring matters to a conclusion. The others entrusted to him the task of drawing up the formal decision. He was Peter Walsh, a Franciscan friar.

Walsh has left us a graphic account of his labours. He spent, he says, three days and nights without sleep, working without interruption, except when, as frequently happened, he was interrupted by members of the Supreme Council-most often by Richard Bellings-coming to urge haste. In such circumstances, his work is a tribute to his stamina almost as much as to his intellect. When he had finished, his treatise was submitted to the theologians, who gave their approval and signed it. Walsh admits that the Jesuits needed persuading, but thirty-one signatures were obtained, including those of the bishops of Meath and Ossory. It was then hastily printed. ${ }^{2}$

It would be a mistake to regard this document as representing solely the views of Walsh, or as solely the fruit of his seventy-two hours' marathon. His ideas must have been taking shape during the long preceding discussions, and his final draft seems to have been quite acceptable to the great majority of those who signed it. Walsh, however, must be considered the real author of this defence of the Supreme Council. He was certainly regarded as such by his contemporaries. $^{3}$ It would seem that he was altogether the author of part of it, for he admits that he made certain additions between the time the document was approved by the theologians and the time it was printed. However, he claims that he had been authorized to make any additions which might strengthen the argument, that everything he added was from the text of the canon law

${ }^{1}$ Comment. Rinucc., vol. III, pp. 482-4 ; Bellings, Ir. confed., vol. VI, pp. 82-5 ; letter of William St. Leger, S.J., in Moran, Spicil. Ossor., vol. I, p. 319; W Walsh, Irish remonstrance, preface to the reader, p. xlvi.

${ }^{2}$ Walsh, op. cit., pp. xliv-xlvi, and first treatise, p. 760 ; Comment. Rinucc., vol. III, pp. $490 \mathrm{f}$.

${ }^{3}$ Walsh's repeated claim to authorship (Irish remonstrance, preface to the reader, p. xliv, first treatise, pp. 584, 760) has plenty of independent support, e.g., Bellings, Ir. confed., vol. VII. 85, Comment. Rinucc., vol. III, pp. 482, 491, 585, vol. IV,
p. 161. 
or from recognized authorities, and that no new objections earned raised when the emended document appeared in print. ${ }^{1}$

From this it would appear that it will be useful to consider Peter Walsh as well as the Queries. There is little definite as to his origins. The notice in the Dictionary of National Biography assumes that he So mu was of the family of Walsh of Mooretown, barony of Salt, co. Kil-1e was dare, ${ }^{2}$ but a contemporary, though very hostile, witness is nottook the so complimentary. ${ }^{3}$ He joined the Franciscan order, and was edu-Jupreme cated at St. Anthony's, Louvain, where he obtained a degree infull text theology. ${ }^{4}$ While in Louvain he came under the influence ofanswers Cornelius Jansen, whom he greatly admired, ${ }^{5}$ though there is no The qr evidence that he ever in later life became a member of the Jansenist ${ }_{1}$. Whet sect. He returned to Ireland in I646 and became a lecturer in the lord theology in the Franciscan convent, Kilkenny. ${ }^{6}$ for an ex

The duties of this post were insufficient to content a man with 2 . Whet an opinion of his powers such as Walsh had. His political career time limi began when he supported the peace of I646. In the following year his sermons attacking the following of the ef year his sermons attacking the nuncio gained him considerable and censt notoriety. ${ }^{7}$ The nuncio's authority at this time was so nearly ab- 3 . Consi solute that Walsh paid the penalty for his rashness. In spite of were offe attempts which were made to save him, he found himself confined able, wh in what was virtually imprisonment in the Franciscan convent of unsatisfa Castledermot. 8 However, the cause with which However, the cause with which he had associated 4 . Whet himself gradually returned to power, and by the time of the Inchiquin the coun truce Walsh was again at large, and again deep in politics.

The contemporary accounts of his character are for the most part from hostile witnesses. They agree that he was capable, but vain in so far as his own powers were concerned. ${ }^{9}$ The description given by William Burgatt is perhaps the most penetrating: "a

5. Whe terdict is tised, an land are contrary countena

1 Irish remonstrance, preface to the reader, p. xlvii. p. 22 .

2 For the family of Walsh of Mooretown see Civil Survey, vol. VIII (Kildare)

${ }^{3}$ Cf. Aphorismical discoverie, vol. I, pp. 236,273 ; and cf. William Burgatt to Propaganda, 11 June 1666, Moran, Spicil. Ossor.,vol. I, p.445 : “ parentibus obscuris."

4 Irish remonstrance, first treatise, p. 608 ; fourth treatise, p. 75 .

5 Ibid., first treatise, p. 568 ; fourth treatise, p. 75.

${ }^{6}$ Ibid., first treatise, p. 586. Talbot, The friar disciplined, p. 44.

7 Irish remonstrance, first treatise, pp. 586-7.

8 Ibid. Ef. also Aphovismical discoverie, vol. I, p. 272.

${ }^{9} \mathrm{Cf}$. William Burgatt to Propaganda, 11 June 1666, Moran, Spicil. Ossor., vol I, p. 445 ; The friar disciplined, pp. 145-7; Comment. Rinucc., vol. V, p. 382.

6. Whe the conf of the ge Catholic solution 7. Whe present Supreme

${ }^{1}$ Querie 
horities, and that no new objections were learned man, of keen intelligence, on which he presumed much ; ed document appeared in print.1 everything is there, the learning, the vanity Walsh's own writingsand the loquacity.

bear that it will be useful to consider Peter ies. There is little definite as to his origins. ary of National Biography assumes that he sh of Mooretown, barony of Salt, co. ary, though very hostile, witness is Kil- he was the principal author. As has been indicated already, it oined the Franciscan order, and is not took the form of answers to seven "queries" propounded by the Louvain, where he obtained a was edu-Supreme Council. It will perhaps be most convenient to give the uvain he came greatly admired, ${ }^{5}$ thou influence of answers will not be necessary. ter life became a member of there is no and in 1646 and became of the Jansenist The queries propounded were the following:

1. Whether any, and if any, what part of the articles of cessation with the lord of Inchiquin, is against the Catholic religion, and just ground
for an excommunication?

n convent, Kilkenny. ${ }^{6}$

were insufficient to content a man with uch as Walsh had. His political career the peace of 1646 . In the following the nuncio gained him considerable uthority at this time was so nearly abpenalty for his rashness. In spite of to save him, he found himself confined isonment in the Franciscan convent of he cause with which he had associated power, and by the time of the Inchiquin irge, and again deep in politics.

its of his character are for the most They agree that he was capable, but rers were concerned. ${ }^{9}$ The description perhaps the most penetrating: "a

reader, p. xlvii.

oretown see Civil Survey, vol. VIII (Kildare),

I. pp. 236, , 273; and cf. William Burgatt to icil. Ossor.,vol. I, p.445 : "parentibus obscuris." 608 ; fourth treatise, p. 75

treatise, p. 75 .

The friar disciplined, p. 44 .

erie, vol. I, p. 272.

da, 11 June 1666, Moran, Spicil. Ossor., vol I,
2. Whether you hold the appeal by us made, and interposed within the be a suspension the canon law, and apostles being granted thereupon, of the effects and the monitory excommunication and interdict, and and censures, in pursuance of the same? and of any other proceedings 3. Considering pursuance of the same ?

3. Considering that the propositions of the lord nuncio now printed were offered by his lordship as a mean to make the cessation conscionable, whether our answers thereto, likewise printed, are so short or excommunication? 4. Whether the ?

the council by opposing of the cessation against the positive order of 5 . Whether it shall be hath sworn the oath of association be perjury ? terdict is against the be found that the said excommunication and intised, and which laws by of the land, as in Catholic times it was pracland are bound to maintain, oath of association all the prelates of this contrary to the positive orders of the Supreships (notwithstanding and countenance or publish the of the Supreme Council to the contrary) 6. Whether a dispensation ma excommunication or interdict ?

the confederation to break the be given to any person or parties of of the general assembly, who framed it as the bon without the consent Catholic confederacy and who framed it as the bond and ligament of the solution whereof bing union in this kingdom; the alteration and dis7. Whether any persons their orders reserved only to themselves ? present proceedings of the of the confederates upon pretence of the Supreme Council? 1 .

${ }^{1}$ Queries, p. ii.

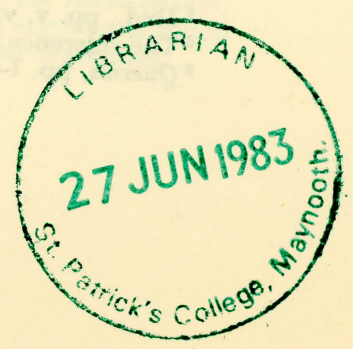


Two things are immediately obvious in these queries. The first is that they are questions framed to expect the answers the Supreme Council desires The second is that whoever drew them up had some acquaintance with the terminology of canon law Naturally, Walsh's opponents accused him of having framed the questions as well as the answers. The point is not of great importance; as has been seen, his authorship even of the answers must be qualified. The responsibility was primarily his, but not altogether. More important is the fact that the Supreme Council did get the answers they so obviously sought.

The queries are followed first by an answer in general terms, which states that the nuncio's censures are not binding, both by reason of defects in the decree of excommunication and because the interposition of the appeal has suspended any effect they might have. ${ }^{1}$ The council thus reassured, Walsh proceeds to give detailed replies to the individual queries.

In reply to the first query, he points out that there is no doubt that a truce between Catholics and heretics is permissible under certain conditions, and that such a truce once made cannot lawfully be broken, so long as the agreed conditions have been observed by the other party to the truce. The truce with Inchiquin has made adequate provision for the Catholic religion, considering the weakness of the confederates and the strength of the enemy. Other Catholic governments have made greater concessions from more favourable positions-Charles V in $\mathrm{I} 547$ and I552, the Emperor Matthias in I609, Philip III of Spain in the same year, Henry III and Henry IV of France, not to mention the long-awaited settlement in Europe, where final agreement, he notes, now seems so near. $^{2}$ Objections were raised in every instance, no doubt, but there was no question of recourse to censure. Neither should there have been in Ireland. The truce was necessary, and religion was adequately provided for. The nuncio's denial of these facts cannot change them; it is indeed difficult to see how he can deny them in view of the care taken by the Supreme Council to ensure that the terms of the truce be emended in accordance with his wishes. ${ }^{3}$

In answer to the second query, Walsh points out that the answer to the first shows that the censures were void in conscience, for they were in fact directed against the first draft of the treaty, not against the emended terms which were those finally agreed to.

1 Ibid., pp. v, vi.

2 The reference is of course to the peace of Westphalia.

Queries, pp. 1-4.

In so far hibit son in the di science. for the a

Walsh It gives canon la and poss which he opinions summari suspensiv applies a the appe a sufficies time pres was rem devolved nuncio $\mathrm{c}$ and that force. I pose for All th nuncio e in the la appear. ${ }^{3}$ nuncio $\mathrm{m}$ appeal. is questi consider raises is cern fait says tha of faith, the decr allowabl

1 Ibid.,

2 Ibid.,

3 These and their preface to $t$ he had rec ${ }^{4}$ Querie 


\section{QUARTERLY}

us in these queries. The first xpect the answers the Supreme noever drew them up had some canon law Naturally, Walsh's amed the questions as well as reat importance; as has been wers must be qualified. The t not altogether. More imCouncil did get the answers

an answer in general terms, res are not binding, both by xcommunication and because spended any effect they might Valsh proceeds to give detailed

its out that there is no doubt heretics is permissible under uce once made cannot lawfully onditions have been observed truce with Inchiquin has made religion, considering the weakrength of the enemy. Other reater concessions from more I547 and I552, the Emperor 1 in the same year, Henry III ntion the long-awaited settleient, he notes, now seems so very instance, no doubt, but censure. Neither should there s necessary, and religion was 's denial of these facts cannot see how he can deny them in ne Council to ensure that the cordance with his wishes. ${ }^{3}$ lsh points out that the answer were void in conscience, for first draft of the treaty, not were those finally agreed to.

\section{THE IRISH CRISIS OF I648: CONCLUSIONS}

In so far as they purport to apply to the final agreement, they prohibit something lawful, namely obedience to the civil government in the discharge of its lawful functions, and are also void in conscience. Since the appeal has been made, they are void in law also, for the appeal has suspended their legal effect. ${ }^{1}$

Walsh now applies himself to this latter, and highly technical, point. It gives him an opportunity of displaying his knowledge of the canon law with a virtuosity through which it would be tedious, and possibly ultimately unprofitable, to follow him. The points which he makes, citing as his authority texts from the decretals and opinions of canonists which he conceives to be relevant, may be summarized as follows: (i) a lawful appeal is suspensive; (ii) this suspensive effect, if it applies to the appeal made by the council, applies also to the nuncio's actions subsequent to the lodging of the appeal ; (iii) in fact, the council's appeal was a lawful one, for a sufficient cause was alleged and the appeal was lodged within the time prescribed by law ; (iv) once the council had appealed the matter was removed from the nuncio's competence, and the decision devolved on the authority to whom the appeal was made; (v) the nuncio cannot maintain that the appeal was merely devolutive, and that in spite of its being admitted the censures were still in force. If this were true, it would be destructive of the whole purpose for which the law grants the right of appeal. ${ }^{2}$

All these points, it will be noted, raise questions to which the nuncio either did not advert or else dismissed as irrelevant. Only in the last two points raised by Walsh does some common ground appear. $^{3}$ In the first of these, he raises the question whether the nuncio may not have power to give a decision which admits of no appeal. He dismisses this as altogether unthinkable where there is question of a just appeal, for to admit such authority must be considered destructive of natural equity. ${ }^{4}$ The second point he raises is that no appeal may be permissible in matters which concern faith. His answer is not particularly convincing, for he simply says that it is very debatable if the question now at issue is a matter of faith, and, even granted that it is, he denies the relevancy of the decretals which have been cited to prove that no appeal is allowable in such cases.

1 Ibid., p. 5.

2 Ibid., pp. 5-17.

3 These may have been added in the time between the approval of the Queries and their being printed (see above, p. 247), for Walsh notes (Irish remonstrance, preface to the reader, p. xlvii), that his additions were meant to meet ar remonstrance, he had received from sources favourable to the nuncio in Galway and Waterford. 
As has been said, it would be tedious, perhaps unprofitable, and certainly a task for an expert in canon law to attempt an evaluation of his arguments from the strictly legal point of view. A few general points may, however, be noted with profit to the present investigation. The most important is that in citing legal texts he appeals always to the law of the decretals. He takes no account of the fact that these had the force of law only in so far as they were not modified by Tridentine and post-Tridentine legislation. Indeed, the complete absence of any reference to post-reformation legal texts in a crisis of an essentially post-reformation character is very significant. ${ }^{1}$ One begins to suspect that Walsh knew very little of Tridentine or post-Tridentine law or, more probably, that he did not wish to appeal to it. ${ }^{2}$

Actually, the only reference to the council of Trent in the whole proceedings in Kilkenny seems to be that which was made in the opening address of the bishop of Ossory, in which he cited what must have been even then a well-worn passage from the decrees of the council which stressed that ecclesiastical authority should look on the weapon of censure as a last resort and should use it sparingly. It was a comfortable reflection, relevant perhaps to the general issue, but somewhat irrelevant to the precise points submitted to the theologians at Kilkenny. They had not been asked to animadvert on the prudence of the nuncio's censures, but on their legal effect.

This absence of any reference to Tridentine legislation in the defence officially adopted by the Supreme Council is noteworthy. It raises an important issue, as yet by no means adequately investigated, namely the relation between the general law of the Catholic church and the discipline of the church in Ireland during

1 Even in 1648, an appeal to the law of the decretals, the Corpus juris canonici, as the immediate and practical norm of law, was full of difficulties. It was particularly full of difficulties in a matter such as the law governing appeals, on which there had been so much Tridentine legislation. It must further be remembered that the office of papal nuncio had developed greatly since the Council of Trent, so that in appeals where a nuncio was concerned even the Tridentine law had dated. See below, p. 256 .

2 To take just one example in some detail. In Quevies, p. 6, in an attempt to find legal authority to prove that the appeal was suspensive, Walsh appeals to a decretal of Celestine III (1191-8), c. 40, X, de appellatione, II, 28. To strengthen his case, he appeals to the mediaeval commentators on the decretals, the glossators, who appear to support his contention. The last glossa on this section of the Corpus iuris canonici was written in 1263 (van Hove, Prolegomena in commentarium Lovaniense, ed. 2 , Louvain, 1945 , p. 473). Walsh makes no appeal to the correctores Romani, who seem opposed to his interpretation. The correctores Romani were a commission appointed to emend the decretals in the light of the Tridentine legislation. Their edition of the decretals was declared the only authentic one by Gregory XIII on 1 July 1580 (van Hove, op. cit., p. 361). It seems fair to infer either that Walsh hed never seen it or that he did not wish to appeal to it. 


\section{AL QUARTERLY}

dious, perhaps unprofitable, and ion law to attempt an evaluation gal point of view. A few general $h$ profit to the present investigain citing legal texts he appeals

He takes no account of the aw only in so far as they were t-Tridentine legislation. Indeed, rence to post-reformation legal st-reformation character is very that Walsh knew very little of or, more probably, that he did

e council of Trent in the whole be that which was made in the Ossory, in which he cited what worn passage from the decrees ecclesiastical authority should a last resort and should use it flection, relevant perhaps to the vant to the precise points subany. They had not been asked the nuncio's censures, but on

o Tridentine legislation in the upreme Council is noteworthy. $t$ by no means adequately intween the general law of the f the church in Ireland during

he decretals, the Corpus juris canonici, as full of difficulties. It was particularly governing appeals, on which there had further be remembered that the office ne Council of Trent, so that in appeals atine law had dated. See below, p. 256. In Quevies, p. 6, in an attempt to find uspensive, Walsh appeals to a decretal ione, II, 28. To strengthen his case, he e decretals, the glossators, who appear his section of the Corpus iuris canonici omena in commentarium Lovaniense, res no appeal to the correctores Romani, correctores Romani were a commission $t$ of the Tridentine legislation. Their y authentic one by Gregory XIII on seems fair to infer either that Walsh peal to it.

\section{THE IRISH CRISIS OF I648: CONCLUSIONS}

the hundred-odd years after the close of the council of Trent. It is true that during the later sixteenth century efforts were made to introduce the Tridentine law, with certain necessary modifications, into Ireland. ${ }^{1}$ The unsettled state of the country made this a difficult task. In addition, partly no doubt owing to the uncertainties of the Irish situation, there seems to have been a certain reluctance on the part of Irish ecclesiastics to accept the Tridentine legislation. That a great deal remained to be done is clear from Rinuccini's instructions, part of which had been that he was to reform the church in Ireland in accordance with the Tridentine decrees. $^{2}$ He got no real opportunity of carrying out this part of his instructions, for his other preoccupations left him little time. An attempt had been made earlier by Scarampi (Nov. I643Sept. I644), but it had encountered difficulties; in particular, there was an insistence on qualifying acceptance with the phrase: "in so far as the circumstances of the time permitted."'3 This reflects what seems to have been the common attitude-that the Tridentine reforms could not be applied fully in Ireland until the church was free from persecution or the threat of persecution. Peter Walsh's Queries seem to suggest further that indifference towards the Tridentine reforms was accompanied by a great measure of practical ignorance of them. ${ }^{4}$

Walsh's replies to the other queries are brief, but in them he develops another point of importance, which may be summarized as follows : seeing that the truce was a lawful one in that it contained adequate safeguards for the Catholic religion, everything connected with the negotiations leading to it lay exclusively within the competence of the civil government, and all subjects, including the prelates, were bound to obey the decisions reached by the civil authority. Therefore, opposition to such a just truce was prohibited by the oath of association of the confederation, which was a just oath taken for the common good. ${ }^{5}$

The fifth query, however, deserves somewhat more detailed consideration, though in a certain sense it lies outside the main line of the attempted justification. It may be noted that Rinuccini had also adverted to the issue it raises, but, even more than the

\footnotetext{
${ }^{1}$ Cf. especially F. M. Jones, "Canonical faculties on the Irish mission in the reign of Queen Elizabeth," in I.T.Q., vol. XX, pp. 152-171 (April, 1953).

${ }^{2}$ Cf. Comment. Rinucc., vol. I, p. 613, vol. II, pp. 177, 182.

3 Ibid., vol. I, pp. $432-43$.

${ }^{4}$ It may be noted that in the section which I have suggested may have been a.dded by Walsh to confute new arguments adduced by supporters of the nuncio, the argument which he has to meet is again based on the law of the decretals.

5 Queries, pp. 21-7.
} 
Supreme Council, he did not base his case on it. Yet in a true sense the issue raised here was fundamental. This may perhaps be the reason why everyone is anxious to keep it in the background. It is in the nature of a last weapon, which neither wishes to invoke, though they are conscious that it best sums up the real difference between the two sides

Perhaps the best way of showing how carefully the matter was approached is simply to repeat the query and give Walsh's reply to it in full. The query was :

5. Whether it shall be found that the said excommunication and interdict is against the law of the land, as in Catholic times it was practised, and which laws by the oath of association all the prelates of this land are bound to maintain, can their lordships (notwithstanding, and contrary to the positive orders of the Supreme Council to the contrary) countenance or publish the said excommunication or interdict?

The phrase "the law of the land as in Catholic times it was practised " may indicate a wish to avoid particulars, and Walsh's reply affords proof of the existence of this wish, for he is even more general, and emphasizes the hypothetical nature of the query. His reply was :

That if it shall be found that the excommunication and interdict of the lord nuncio is against the fundamental laws of the kingdom, and which the prelates have sworn by the oath of association to maintain, it is not lawful for them to publish or countenance the said censure contrary to your lordships' positive orders. Neither do we see how can any of the prelates otherwise answer, if they condemn not the oath of association of injustice, and themselves in having done ill in taking or approving it. ${ }^{1}$

From this reply it will be clear that Walsh is even more careful than the Supreme Council. One thing which may be deduced from his opening phrase is that he considered the decision to be one for civil rather than for canon law. From the way in which the council's question is phrased it also seems a reasonable deduction that they are referring primarily to the statutes of provisors and praemunire. In this we have perhaps the clearest indication of the outlook of the Supreme Council and their supporters. Rinuccini's reaction, on the other hand, shows that to the mind of an Italian ecclesiastic of the counter-reformation these enactments were barely memories of a day which was long past. In his report to Rome on I5 June I648 he had given as his last reason for having had recourse to excommunication:

1 Ibid., p. 22. 
is case on it. Yet in a true sense ntal. This may perhaps be the keep it in the background. It which neither wishes to invoke, best sums up the real difference

ig how carefully the matter was e query and give Walsh's reply

e said excommunication and interin Catholic times it was practised, ation all the prelates of this land dships (notwithstanding, and consupreme Council to the contrary) mmunication or interdict?

nd as in Catholic times it was avoid particulars, and Walsh's of this wish, for he is even more othetical nature of the query.

excommunication and interdict of mental laws of the kingdom, and e oath of association to maintain, or countenance the said censure orders. Neither do we see how wer, if they condemn not the oath elves in having done ill in taking

that Walsh is even more careful ing which may be deduced from asidered the decision to be one v. From the way in which the seems a reasonable deduction o the statutes of provisors and aps the clearest indication of the d their supporters. Rinuccini's that to the mind of an Italian on these enactments were barely $\mathrm{g}$ past. In his report to Rome his last reason for having had my enemies declare my inability as a foreign power to excommunicate in this kingdom, in virtue of I know not what English laws (in vigore di non so che leggi anglicane); consequently, had I spared the censure, the people ran the risk of being confirmed in this belief, and the English laws which the Holy See has always opposed would have taken root by my tacit consent. ${ }^{1}$

We have here, it would seem, the clearest indication so far of the sources of resistance to Rinuccini. The statutes of provisors and praemunire did not fit into the scheme of the counter-reformation, but they were still a reality to the Supreme Council. In s ummarizing Rinuccini's defence, it has been seen that it was an amalgam of text-book orthodoxy and failure to realize how events were modifying the text-books. The Council's case is similarly composed, though they are working from different text-books. In one respect their text-books are more antiquated, in another they are less so, for, as has been seen somewhat more clearly in the later controversies, ${ }^{2}$ the pre-reformation traditions of royal ecclesiastical rights have by $\mathrm{I} 648$ been influenced by newer theories of the source and extent of royal authority.

\section{CONCLUSION}

The fact is that the whole question of relations between church and state was in rapid change during the period under discussion, and neither side to the dispute was fully aware of all the developments. As has just been noted, the Irish who opposed Rinuccini seem to have based their stand on a legal system which, while it had served its purpose reasonably well in times past, was in no way fitted to the situation existing in the middle of the seventeenth century. The laws of the decretals and the statutes of provisors and praemunire, which in theory were in direct conflict, had in practice provided a delicate balance of rights, usually resulting in endless appeals and argument. These were a luxury which the Catholic church could not afford in the new and revolutionary times. The old forms of law had worked when there had been no disagreement on fundamentals. Long argument could be tolerated when the debate could be conducted within an agreed system.

This system was in decay even before the religious revolution

1 “ Ragioni per le quali," Nunziatura, p. 318.

2 Notably in the case of John Callaghan; somewhat less notably with John Lynch and Richard Bellings. 
of the sixteenth century destroyed it completely. The statutes of provisors and praemunire were themselves indications of the diffculties to come. Although they had become law in a Catholic England, ${ }^{1}$ it has many times been pointed out how naturally they were the precursors of the legislation of Henry VIII. With the sixteenth-century changes, the nation-state had gained new coherence, and friction inevitably intensifies between its claims and those of the Catholic church. This friction was not confined to Protestant states, though it was naturally most marked in them ; but even in Catholic countries the doctrine of the divine office of the Pope and of the divine right of kings did not easily agree.

The Catholic church was not blind to the problems of the times, but contemporaries can never see their own age with the perspective granted to later generations, and in all large institutions there is an inevitable force of inertia. The church, however, was alive to the fact that the new revolutionary situation did demand a tightening up of discipline and the taking of decisions in a more summary way.

Again, because of the development of the nation-states of Europe, the importance of the diplomatic missions of the church increased considerably at this time. The late sixteenth and early seventeenth centuries saw the effective establishment of permanent diplomatic missions. The papal nuncios were usually entrusted with powers of a very wide and summary nature, and such powers were necessary. ${ }^{2}$ With regard to the use of these powers, a great deal of discretion had to be left to the individual nuncio, for the government of the church, if not too certain of the new shape of things, was conscious that it was in fairly rapid change and that an insistence on what were conceived to be full rights might not be diplomatically advantageous. Such insistence might lead to difficulties with governments, Catholic no less than Protestant, for both were insistent

\footnotetext{
1 On the extension of these statutes to Ireland, see especially St. John D. Seymour, "The mediaeval church," in W. A. Phillips (ed.), History of the church of Ireland, vol. II, pp. $112 \mathrm{ff}$. It might be remarked that if the list of instances of these statutes being invoked which he gives is meant to be in any way exhaustive, they must have been invoked very infrequently indeed. On the other hand, it must be remembered that the chief importance of these laws did not lie in the fact that they were the law of the land, if only because the logical consequence of invoking them in any consistent way was immediate schism. They are important rather as evidence of the outlook which led to their enactment, and which in turn they nourished. If the above analysis is correct, it would seem that this mentality was not negligible in prereformation Ireland, at least in Anglo-Irish Ireland, and that as a mentality it managed to survive the counter-reformation until 1648. It might be put differently by saying that Cromwell's decimation of the Catholic aristocracy may have prevented many temptations to an " Irish Gallicanism," or the emergence of Irish " protesting Catholic dissenters."

2 For a convenient summary, cf. Paro, The right of papal legation, pp. 111-35.
}

on
It
repr
the
papa
the
the
$A_{8}$
into
of th
vario
The

called

For a shoulc diplon

Thi:

Even

ablethe q1 warnir himsel

Ther action some dishon he mu. of a d author it was himsel the pr: the $\mathrm{Ol}$ interes than $\mathrm{d}$ but it nuncio inflexib That, 1 
oyed it completely. The statutes of e themselves indications of the diffihey had become law in a Catholic been pointed out how naturally they gislation of Henry VIII. With the nation-state had gained new cohertensifies between its claims and those iction was not confined to Protestant ly most marked in them; but even rine of the divine office of the Pope s did not easily agree.

$t$ blind to the problems of the times, ee their own age with the perspective and in all large institutions there is The church, however, was alive to nary situation did demand a tightenking of decisions in a more summary

pment of the nation-states of Europe, atic missions of the church increased late sixteenth and early seventeenth ablishment of permanent diplomatic vere usually entrusted with powers of re, and such powers were necessary. ${ }^{2}$ se powers, a great deal of discretion al nuncio, for the government of the e new shape of things, was conscious inge and that an insistence on what ats might not be diplomatically adnight lead to difficulties with governProtestant, for both were insistent

o Ireland, see especially St. John D. Seymour, hillips (ed.), History of the church of Ireland, ked that if the list of instances of these statutes to be in any way exhaustive, they must have 1. On the other hand, it must be remembered s did not lie in the fact that they were the law consequence of invoking them in any consistent important rather as evidence of the outlook which in turn they nourished. If the above at this mentality was not negligible in prerish Ireland, and that as a mentality it managed il 1648. It might be put differently by saying tholic aristocracy may have prevented many " or the emergence of Irish " protesting Cath-

o, The right of papal legation, pp. 111-35. on what they for their part believed to be their rights.

It must be remembered too that there was also inherent in the new developments the possibility of a clash between the papal representative and the local episcopate. The Catholic reforms of the sixteenth century had tried to tighten the control of the central papal authority and at the same time make real the authority of the diocesan bishop. Both steps were necessary, but they contained the elements of conflict.

Against this background events in Ireland in I648 begin to come into focus. Rinuccini was very conscious of the developments of the central authority, much less conscious, it would seem, of the various forces of resistance to it which were developing elsewhere. The office of nuncio, especially in the complex Irish situation, called for a flexibility of approach which he seems to have lacked. For all his acute powers of observation, it is very arguable that he should never have been entrusted with the responsibilities of a diplomat.

This appears very strikingly in his excommunication of $\mathrm{I} 648$. Even if his authority to invoke the censure had been unquestionable-and Robert O'Connell has at least left doubts-there remained the question of prudence. Rinuccini should have had sufficient warnings from many sources to give him pause. Instead, he allowed himself to be swept off his feet by the crisis of the moment.

There can be no doubt that he himself was convinced that his action was ultimately legal. Rinuccini, in spite of the charges of some of his opponents, never gives the impression of arguing a dishonest case. Yet, in spite of the way events forced his hand, he must be judged to have failed in some degree in the prudence of a diplomat. To pronounce censure in circumstances where his authority could be called into question was sufficiently serious; it was worse that in the end Rinuccini should have committed himself to a position he had long been consciously trying to avoidthe practical identification of his policy with that of O'Neill and the Old-Irish. When this happened, a clash with the political interest opposed to O'Neill could no longer be avoided. It is more than doubtful if such a clash could have been avoided in any case, but it was a pity that the occasion should be supplied by the papal nuncio's lack of flexibility, which here clashed with another very inflexible institution, the social organization of Ireland at the time. That, however, is another question. 